\title{
Dilatation of the Great Arteries in an Infant with Marfan Syndrome and Ventricular Septal Defect
}

\author{
L. Rozendaal, ${ }^{1}$ N. A. Blom, ${ }^{1,2}$ Y. Hilhorst-Hofstee, ${ }^{3}$ and A. D. J. Ten Harkel ${ }^{1}$ \\ ${ }^{1}$ Department of Pediatric Cardiology, Willem Alexander Children and Youth Center, Leiden University Medical Center, \\ P.O. Box 9600, 2300 RC Leiden, The Netherlands \\ ${ }^{2}$ Department of Pediatric Cardiology, Emma Children's Hospital AMC, Academic Medical Center, \\ 1105 AZ Amsterdam, The Netherlands \\ ${ }^{3}$ Department of Clinical Genetics, Leiden University Medical Center, 2300 RC Leiden, The Netherlands
}

Correspondence should be addressed to L. Rozendaal, l.rozendaal@lumc.nl

Received 18 March 2011; Accepted 18 May 2011

Academic Editor: Ron Rabinowitz

Copyright () 2011 L. Rozendaal et al. This is an open access article distributed under the Creative Commons Attribution License, which permits unrestricted use, distribution, and reproduction in any medium, provided the original work is properly cited.

We describe an infant presenting with contractures of the fingers, a large ventricular septal defect (VSD), and severe pulmonary artery dilatation. He had clinical and echocardiographic features of both neonatal or infantile Marfan syndrome (MFS) and congenital contractural arachnodactyly. After surgical VSD closure, the aortic root developed progressive dilatation while the size of pulmonary artery returned to normal limits. Eventually the diagnosis of MFS was confirmed by DNA analysis.

\section{Introduction}

In infancy the diagnosis of Marfan syndrome may be difficult, and clinical presentation and prognosis are variable. We present a special case of infantile Marfan syndrome with a congenital heart disease.

\section{Clinical Presentation}

Our patient is a boy born to healthy parents (father is 37 years old, mother is 29 years old), who lives in Surinam. The pregnancy was uneventful, and he was born at a normal term. He had two healthy sisters of 6 and 9 years old. Family history was noncontributory. At the age of 4 months he developed heart failure and echocardiographic examination showed a large ventricular septal defect (VSD) and atrial septal defect (ASD) secundum type. The patient was sent to our institution for cardiac surgery at the age of 8 months. Physical examination showed a tall and dystrophic boy with a height of $75.0 \mathrm{~cm}(+1.5 \mathrm{SDS})$, weight of $5.5 \mathrm{~kg}(<-2.5$ SDS), and an arm span of $72.0 \mathrm{~cm}$ (ratio arm span/height is 0.96$)$. His target height is $187 \mathrm{~cm}(+0.4 \mathrm{SDS})$. He had no distinguished facial anomalies with a normal palate and normal ears. He had a pectus carinatum, arachnodactyly, and contractures of both proximal interphalanges of the third and fourth digits. He was dyspnoeic and tachypnoeic, and cardiac examination showed a hyperdynamic precordium, fixed splitting of the second heart sound, and no cardiac murmurs. Echocardiography showed a secundum-type ASD and a $17 \mathrm{~mm}$ muscular inlet VSD with a large left- toright shunt causing pulmonary flow hypertension. The right atrium and right ventricle were dilated. Both mitral valve (MV) and tricuspid valve (TV) had a mild prolapse with a normal function. The pulmonary valve (PV), trunk, and branches were severely dilated with the diameter of the main pulmonary artery of $27.5 \mathrm{~mm}$ (Table 1 and Figure 1). The tricuspid aortic valve (AoV) showed normal function, and the aortic root diameter was dilated (Table 1). Surgical correction included primary closure of the ASD and closure of the VSD with a Gore-Tex patch. The postoperative course was uneventful with prompt recovery. Based on the clinical and echocardiographic features the differential diagnosis consisted of congenital contractural arachnodactyly (CCA) and neonatal or infantile Marfan syndrome (MFS). At that 


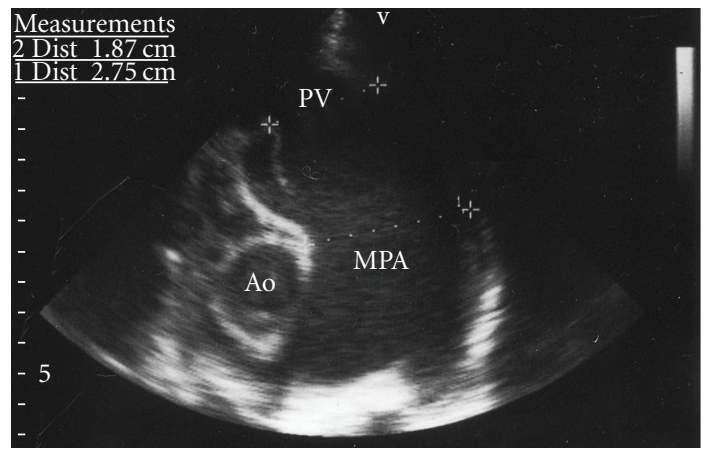

(a)

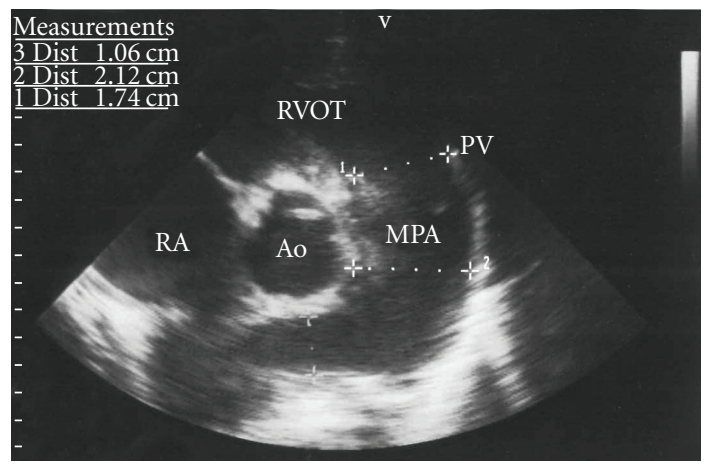

(b)

FIgURE 1: Parasternal short-axis view of the pulmonary valve (PV) and main pulmonary artery (MPA) of the patient preoperatively (a) and directly postoperatively (b). The severe dilatation of the PV (diameter $22 \mathrm{~mm}$ ) and MPA (diameter $27 \mathrm{~mm}$ ) diminished directly postoperatively, almost to normal limits $(17.4 \mathrm{~mm}$ and $21.2 \mathrm{~mm}$, resp.). RA: right atrium; RVOT: right ventricle outflow tract; Ao: aorta.

time no further gene testing was performed. After recovery the patient went home to Surinam, where the followup continued up to an age of 6 years.

During followup his height was excessive (SDS $>2.5$ ), the contractures of the fingers were progressive, and he was wearing glasses because of myopia. Psychomotor development was normal. Interestingly, echocardiographic examinations showed significant decrease of diameters of the pulmonary valve and main pulmonary artery directly after operation which remained within normal limits during followup (Table 1, Figure 1). However, the diameter of the aortic root increased from 22 to $23.4 \mathrm{~mm}$ directly after operation and with progressive dilatation to $38.7 \mathrm{~mm}$ during followup (Table 1, Figure 2). Thus far, aortic valve function remained normal. The mild prolapse of the mitral valve remained stable with trivial mitral regurgitation. Because of progressive aortic root dilatation beta-blocking therapy was started at the age of 5 years.

At that time-gene testing was performed to further differentiate between infantile MFS and CCA. Using denaturing high-performance liquid chromatography (DHPLC), multiplex ligation-dependent probe amplification (MLPA kit P065/P066 v3), and DNA sequence-analysis in 2008, we found a frameshift mutation encoding a stop-mutation in the

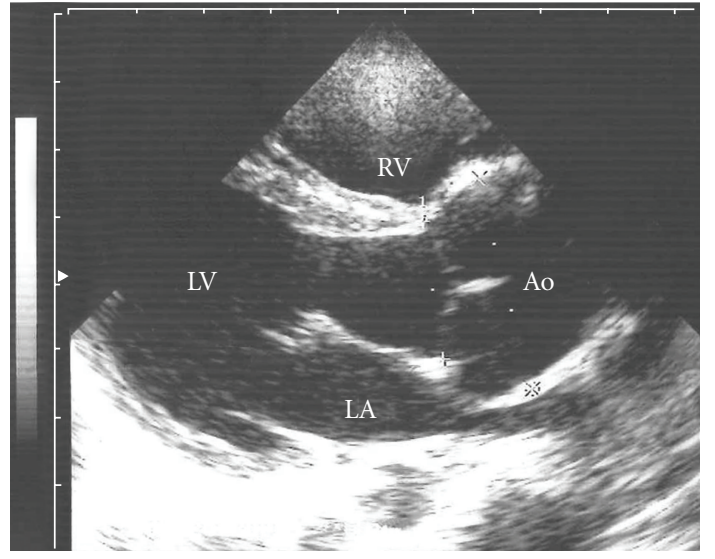

Figure 2: Parasternal long-axis view of left ventricle (LV) shows severe dilatation of the aortic root at the age of almost 4 years. Diameter of the aortic root is $32.2 \mathrm{~mm}$. LA: left atrium; LV: left ventricle; RV: right ventricle; Ao: aorta.

FBN1 gene c.3396delA (p.Glu1133ArgfsX29) confirming the diagnosis of infantile Marfan syndrome.

\section{Discussion}

In infancy, the diagnosis of MFS can be differentiated in neonatal MFS, severe infantile MFS or early-onset form of MFS, and infants with a positive family mutation without major features at that moment. Differentiation is important because treatment and prognosis will be different, but this may be difficult [2-6]. Marfan syndrome is an autosomal dominant inherited disorder of connective tissue in which ocular, skeletal, cardiovascular, integumentary, pulmonary, and neurological features may be present in a highly variable degree [7-9]. The diagnosis is still a clinical one, based on fulfillment of diagnostic criteria [10]. It is caused by missense mutations in FBN1 gene [11] on chromosome 15q21.1, the gene encoding fibrillin-1, a principle component of extracellular matrix microfibrils. A Marfan-like phenotype can be caused by mutations in the TGFBR2 gene on chromosome 3, encoding TGF-beta receptor 2 [12]. In the classic form of Marfan syndrome, isolated occurrence is in $25-35 \%$ of the patients. Fibrillin indirectly controls TGFbeta activation, and dysregulation of TGF-beta may play a role in the pathophysiology of Marfan syndrome [13-23]. Main cardiovascular features are aortic root dilatation and/or aorta dissection and MV prolapse. Prognosis is mainly determined by progressive aortic root dilatation, potentially resulting in dissection and rupture. Prophylactic aortic root repair has raised the life expectancy by 30 years or more $[24,25]$.

Neonatal Marfan syndrome is a different group of patients with $50 \%$ mortality before the first year of life caused by heart failure. The definition of neonatal Marfan syndrome is an estimated diagnosis before 3 months of age, congenital pulmonary emphysema, severe atrioventricular valve (TV and MV) regurgitation in combination with congenital arachnodactyly, contractures, megalocornea, iridodonesis, rocker bottom feet, crumpled ears, and loose skin 
TABLE 1: Aortic root diameters and pulmonary artery diameters during followup.

\begin{tabular}{lcccccc}
\hline $\begin{array}{c}\text { Age } \\
(\mathrm{yr})\end{array}$ & $\begin{array}{c}\text { Height } \\
\mathrm{cm}(\mathrm{SDS})\end{array}$ & $\begin{array}{c}\text { Weight } \\
(\mathrm{SDS})\end{array}$ & $\begin{array}{c}\text { BSA } \\
\left(\mathrm{m}^{2}\right)\end{array}$ & $\begin{array}{c}\text { Aortic root } \\
\mathrm{mm}(z \text {-score })\end{array}$ & $\begin{array}{c}\text { PV } \\
\mathrm{mm}(z \text {-score })\end{array}$ & $\begin{array}{c}\text { MPA } \\
\mathrm{mm}(z \text {-score })\end{array}$ \\
\hline 0.7 & $75.0(+1.5)$ & $5.5(<-2.5)$ & 0.34 & $22.0(+8.6)$ & $22.0(+6.2)$ & $27.5(+8)$ \\
0.8 & $75.1(+1.5)$ & $5.6(<-2.5)$ & 0.34 & $23.4(+9.2)$ & $17.4(+4.0)$ & $21.2(+6)$ \\
3.7 & $114.7(>+2.5)$ & $16.0(<-2.5)$ & 0.73 & $32.3(+8.4)$ & $20.0(+1.9)$ & $21.0(+2)$ \\
5.7 & $129.0(+2.5)$ & $18.0(<-2.5)$ & 0.83 & $38.7(+9.9)$ & $19.0(+0.9)$ & $19.1(+1)$ \\
\hline
\end{tabular}

BSA: body surface area; PV: pulmonary valve; MPA: main pulmonary artery. $z$-score according to Daubeney ([1], 284/id).

$[3,26,27]$. Especially congenital pulmonary emphysema and MV and/or TV insufficiency are very common (specific) in neonatal Marfan syndrome [3, 28]. The mutations are located in the central region of the FBN1 gene (exons 2432 ) and all are de novo mutations. However, mutations of patients with the classic form of Marfan syndrome have also been found in this region $[4,6,26,28-36]$.

Clinically our patient had severe infantile Marfan syndrome, early diagnosed because of the symptoms of a large ASD and VSD. We found a severely dilated pulmonary artery before operation, due to a large left-to-right shunt and pulmonary flow hypertension. Although pulmonary artery dilatation is a common finding in patients of all ages with MFS [37, 38], this case illustrates that the main pulmonary artery can dilate extremely due to increased pulmonary artery pressure and flow which appeared to be reversible after normalization of pulmonary artery pressure. In contrast, the aortic root showed progressive dilatation after shunt closure and improvement of left ventricular cardiac output. Congenital heart disease in MFS is rare and only a few cases have been described in literature [2, 4, 39-52]. Patent ductus arteriosus and atrial septal defect have been described in $4-6 \%$ of the patients $[2,4,39,41,44,47,51]$ and may need surgical or interventional closure. The use of septal occluders should be considered with caution in the Marfan syndrome, because of risk of penetration [47]. An isolated VSD, without complex heart defect, as in our patient, has been reported in only 5 cases (infants and adults) in literature over the last 40 years [39-41, 46, 50, 52]. Coarctation of the aorta was reported once in a 10-year-old girl [45]. Three cases with complex congenital heart disease were described [42, 48, 49]. Congenital heart disease appears to be more common in Beals-Hecht syndrome or congenital contractural arachnodactyly (CCA), a dominantly inherited disorder of connective tissue characterized by multiple contractures, arachnodactyly, dolichostenomelia, scoliosis, and external ear anomalies, with mutations in FBN2 gene $[53,54]$. Skeletal features are almost the same as in Marfan syndrome, and dilatation of the aortic root and mitral valve prolapse, although less common, can also occur in CCA. The congenital heart defects described in CCA are very similar to those in MFS, including ASD, VSD, patent ductus arteriosus, coarctation, or interruption of the aorta $[55,56]$.

\section{Conclusion}

This special case of infantile MFS with congenital heart disease demonstrates severe dilatation of both great arteries with reversibility of pulmonary artery dilatation after normalization of the pulmonary artery pressure. It further illustrates that the clinical phenotypes of MFS and CCA show significant overlap and that genetic testing was required for final differentiation.

$\begin{array}{ll}\text { Abbreviations } \\ \text { AoV: } & \text { Aortic valve } \\ \text { ASD: } & \text { Atrial septal defect } \\ \text { CCA: } & \text { Congenital contractural arachnodactyly } \\ \text { FBN1: } & \text { Fibrillin-1 } \\ \text { FBN2: } & \text { Fibrillin-2 } \\ \text { MFS: } & \text { Marfan syndrome } \\ \text { MPA: } & \text { Main pulmonary artery } \\ \text { MV: } & \text { Mitral valve } \\ \text { PV: } & \text { Pulmonary valve } \\ \text { SDS: } & \text { Standard deviation score } \\ \text { TV: } & \text { Tricuspid valve } \\ \text { TGFBR2: } & \text { TGF-beta receptor } 2 \\ \text { TGF: } & \text { Tissue growth factor } \\ \text { VSD: } & \text { Ventricular septal defect. }\end{array}$

\section{References}

[1] P. E. Daubeney, E. H. Blackstone, R. G. Weintraub, Z. Slavik, J. Scanlon, and S. A. Webber, "Relationship of the dimension of cardiac structures to body size: an echocardiographic study in normal infants and children," Cardiology in the Young, vol. 9, no. 4, pp. 402-410, 1999.

[2] T. Geva, S. P. Sanders, M. S. Diogenes, S. Rockenmacher, and R. Van Praagh, "Two-dimensional and Doppler echocardiographic and pathologic characteristics of the infantile Marfan syndrome," The American Journal of Cardiology, vol. 65, no. 18, pp. 1230-1237, 1990.

[3] R. C. Hennekam, "Severe infantile Marfan syndrome versus neonatal Marfan syndrome," American Journal of Medical Genetics, vol. 139, no. 1, pp. 1-15, 2005.

[4] R. P. Morse, S. Rockenmacher, R. E. Pyeritz et al., "Diagnosis and management of infantile Marfan syndrome," Pediatrics, vol. 86, no. 6, pp. 888-895, 1990.

[5] F. Tiecke, S. Katzke, P. Booms et al., "Classic, atypically severe and neonatal Marfan syndrome: twelve mutations and genotype-phenotype correlations in FBN1 exons 24-40," European Journal of Human Genetics, vol. 9, no. 1, pp. 13-21, 2001.

[6] M. Wang, J. Y. Wang, J. Cisler et al., "Three novel fibrillin mutations in exons 25 and 27: classic versus neonatal Marfan syndrome," Human Mutation, vol. 9, no. 4, pp. 359-362, 1997.

[7] V. A. Mckusick, “The cardiovascular aspects of Marfan's syndrome: a heritable disorder of connective tissue," Circulation, vol. 11 , no. 3, pp. 321-342, 1955. 
[8] R. E. Pyeritz, “The Marfan syndrome," Annual Review of Medicine, vol. 51, pp. 481-510, 2000.

[9] R. E. Pyeritz and V. A. Mckusick, "The Marfan syndrome: diagnosis and management," New England Journal of Medicine, vol. 300, no. 14, pp. 772-777, 1979.

[10] A. De Paepe, R. B. Devereux, H. C. Dietz, R. C. M. Hennekam, and R. E. Pyeritz, "Revised diagnostic criteria for the Marfan syndrome," American Journal of Medical Genetics, vol. 62, no. 4, pp. 417-426, 1996.

[11] B. Lee, M. Godfrey, E. Vitale et al., "Linkage of Marfan syndrome and a phenotypically related disorder to two different fibrillin genes," Nature, vol. 352, no. 6333, pp. 330-334, 1991.

[12] T. Mizuguchi, G. Collod-Beroud, T. Akiyama et al., "Heterozygous TGFBR2 mutations in Marfan syndrome," Nature Genetics, vol. 36, no. 8, pp. 855-860, 2004.

[13] P. H. Byers, "Determination of the molecular basis of Marfan syndrome: a growth industry," Journal of Clinical Investigation, vol. 114, no. 2, pp. 161-163, 2004.

[14] S. L. Dallas, D. R. Keene, S. P. Bruder et al., "Role of the latent transforming growth factor beta binding protein 1 in fibrillincontaining microfibrils in bone cells in vitro and in vivo," Journal of Bone and Mineral Research, vol. 15, no. 1, pp. 68$81,2000$.

[15] G. De Crescenzo, S. Grothe, J. Zwaagstra, M. Tsang, and M. D. O'Connor-McCourt, "Real-time monitoring of the interactions of transforming growth factor-beta (TGF-beta) isoforms with latency-associated protein and the ectodomains of the TGF-beta Type II and III receptors reveals different kinetic models and stoichiometries of binding," Journal of Biological Chemistry, vol. 276, no. 32, pp. 29632-29643, 2001.

[16] Z. Isogai, R. N. Ono, S. Ushiro et al., "Latent transforming growth factor beta-binding protein 1 interacts with fibrillin and is a microfibril-associated protein," Journal of Biological Chemistry, vol. 278, no. 4, pp. 2750-2757, 2003.

[17] V. Kaartinen and D. Warburton, "Fibrillin controls TGF-beta activation," Nature Genetics, vol. 33, no. 3, pp. 331-332, 2003.

[18] T. Kanzaki, A. Olofsson, A. Moren et al., "TGF-beta 1 binding protein: a component of the large latent complex of TGFbeta 1 with multiple repeat sequences," Cell, vol. 61, no. 6, pp. 1051-1061, 1990.

[19] K. Miyazono, A. Olofsson, P. Colosetti, and C. H. Heldin, "A role of the latent TGF-beta 1-binding protein in the assembly and secretion of TGF-beta 1," EMBO Journal, vol. 10, no. 5, pp. 1091-1101, 1991.

[20] E. R. Neptune, P. A. Frischmeyer, D. E. Arking et al., "Dysregulation of TGF-beta activation contributes to pathogenesis in Marfan syndrome," Nature Genetics, vol. 33, no. 3, pp. 407411, 2003.

[21] J. Saharinen, M. Hyytiainen, J. Taipale, and J. Keski-Oja, "Latent transforming growth factor-beta binding proteins (LTBPs)—sructural extracellular matrix proteins for targeting TGF-beta action," Cytokine and Growth Factor Reviews, vol. 10, no. 2, pp. 99-117, 1999.

[22] J. Saharinen and J. Keski-Oja, "Specific sequence motif of 8Cys repeats of TGF-beta binding proteins, LTBPs, creates a hydrophobic interaction surface for binding of small latent TGF-beta," Molecular Biology of the Cell, vol. 11, no. 8, pp. 2691-2704, 2000.

[23] J. Saharinen, J. Taipale, and J. Keski-Oja, "Association of the small latent transforming growth factor-beta with an eight cysteine repeat of its binding protein LTBP-1," EMBO Journal, vol. 15, no. 2, pp. 245-253, 1996.
[24] R. E. Pyeritz, "Marfan syndrome: 30 years of research equals 30 years of additional life expectancy," Heart, vol. 95, no. 3, pp. 173-175, 2009.

[25] D. I. Silverman, K. J. Burton, J. Gray et al., "Life expectancy in the Marfan syndrome," The American Journal of Cardiology, vol. 75, no. 2, pp. 157-160, 1995.

[26] P. Booms, J. Cisler, K. R. Mathews et al., "Novel exon skipping mutation in the fibrillin-1 gene: two 'hot spots' for the neonatal Marfan syndrome," Clinical Genetics, vol. 55, no. 2, pp. 110-117, 1999.

[27] N. Revencu, G. Quenum, T. Detaille, G. Verellen, A. De Paepe, and C. Verellen-Dumoulin, "Congenital diaphragmatic eventration and bilateral uretero-hydronephrosis in a patient with neonatal Marfan syndrome caused by a mutation in exon 25 of the FBN1 gene and review of the literature," European Journal of Pediatrics, vol. 163, no. 1, pp. 33-37, 2004.

[28] H. T. Heide, C. T. Schrander-Stumpel, G. Pals, and T. Delhaas, "Neonatal Marfan syndrome: clinical report and review of the literature," Clinical Dysmorphology, vol. 14, no. 2, pp. 81-84, 2005.

[29] T. Abdel-Massih, A. Goldenberg, P. Vouhe et al., "Marfan syndrome in the newborn and infant less than 4 months: a series of 9 patients," Archives des Maladies du Coeur et des Vaisseaux, vol. 95, no. 5, pp. 469-472, 2002.

[30] I. M. Buntinx, P. J. Willems, S. E. Spitaels, P. J. Van Reempst, A. M. De Paepe, and J. E. Dumon, "Neonatal Marfan syndrome with congenital arachnodactyly, flexion contractures, and severe cardiac valve insufficiency," Journal of Medical Genetics, vol. 28, no. 4, pp. 267-273, 1991.

[31] N. H. Elcioglu, F. Akalin, M. Elcioglu, P. Comeglio, and A. H. Child, "Neonatal Marfan syndrome caused by an exon 25 mutation of the Fibrillin-1 gene," Genetic Counseling, vol. 15, no. 2, pp. 219-225, 2004.

[32] M. A. Gruber, T. P. Graham Jr., E. Engel, and C. Smith, "Marfan syndrome with contractural arachnodactyly and severe mitral regurgitation in a premature infant," Journal of Pediatrics, vol. 93, no. 1, pp. 80-82, 1978.

[33] A. M. Jacobs, I. Toudjarska, A. Racine, P. Tsipouras, M. W. Kilpatrick, and A. Shanske, "A recurring FBN1 gene mutation in neonatal Marfan syndrome," Archives of Pediatrics and Adolescent Medicine, vol. 156, no. 11, pp. 1081-1085, 2002.

[34] P. Ramaswamy, I. D. Lytrivi, K. Nguyen, and B. D. Gelb, "Neonatal Marfan syndrome: in utero presentation with aortic and pulmonary artery dilatation and successful repair of an acute flail mitral valve leaflet in infancy," Pediatric Cardiology, vol. 27, no. 6, pp. 763-765, 2006.

[35] M. Tekin, F. B. Cengiz, E. Ayberkin et al., "Familial neonatal Marfan syndrome due to parental mosaicism of a missense mutation in the FBN1 gene," American Journal of Medical Genetics, vol. 143, no. 8, pp. 875-880, 2007.

[36] M. Wang, P. Kishnani, M. Decker-Phillips, S. G. Kahler, Y. T. Chen, and M. Godfrey, "Double mutant fibrillin-1 (FBN1) allele in a patient with neonatal Marfan syndrome," Journal of Medical Genetics, vol. 33, no. 9, pp. 760-763, 1996.

[37] B. J. De, B. Loeys, D. Devos, H. Dietz, S. J. De, and P. A. De, "A critical analysis of minor cardiovascular criteria in the diagnostic evaluation of patients with Marfan syndrome," Genetics in Medicine, vol. 8, no. 7, pp. 401-408, 2006.

[38] G. J. Nollen, K. E. van Schijndel, J. Timmermans et al., "Pulmonary artery root dilatation in Marfan syndrome: quantitative assessment of an unknown criterion," Heart, vol. 87, no. 5, pp. 470-471, 2002. 
[39] M. Bauer, H. Siniawski, U. Bauer et al., "Ventricular septal aneurysm in a patient with Marfan syndrome," Zeitschrift fur Kardiologie, vol. 89, no. 8, pp. 702-705, 2000.

[40] N. L. Bilgrami, S. G. Tewari, M. Aslam, and Z. A. Khan, "Marfan syndrome with microcornea, aphakia and ventricular septal defect. Case report," Indian Heart Journal, vol. 33, no. 2, pp. 78-80, 1981.

[41] R. P. Bolande and A. S. Tucker, "Pulmonary emphysema and other cardiorespiratory lesions as part of the Marfan abiotrophy," Pediatrics, vol. 33, pp. 356-366, 1964.

[42] R. W. Childers and P. C. McCrea, "Absence of the pulmonary valve. A case occuring in the Marfan syndrome," Circulation, vol. 29, pp. 598-603, 1964.

[43] C. C. Cronin and A. M. Harris, "Atrial fibrillation and interatrial septal aneurysm in a patient with Marfan's syndrome," International Journal of Cardiology, vol. 34, no. 1, pp. 115-117, 1992.

[44] S. Figueiredo, E. Martins, M. R. Lima, and S. Alvares, "Cardiovascular manifestations in Marfan syndrome," Revista Portuguesa de Cardiologia, vol. 20, no. 12, pp. 1203-1218, 2001.

[45] R. N. Headley, H. M. Carpenter, and C. G. Sawyer, "Unusual features of Marfan's syndrome including two postmortem studies," The American Journal of Cardiology, vol. 11, no. 2, pp. 259-266, 1963.

[46] P. Karoly, B. Gyorgy, and B. Kornél, "Isolated ventricular septal defect in Marfan's syndrome," Orvosi Hetilap, vol. 110, no. 23, pp. 1325-1328, 1969.

[47] F. Loeffelbein, C. Schlensak, and S. Dittrich, "Penetration of left and right atrial wall and aortic root by an Amplatzer atrial septal occluder in a nine year old boy with Marfan syndrome: case report," Journal of Cardiothoracic Surgery, vol. 3, article 25, no. 1, 2008.

[48] R. Metelka, J. Dusek, and J. Vomacka, "Dextrocardia and Marfan's syndrome," Acta Universitatis Palackianae Olomucensis Facultatis Medicae, vol. 133, pp. 43-45, 1992.

[49] D. Nathan, J. Kraus, V. Deutsch, and H. N. Neufeld, "Dilatation of the aorta and pulmonary artery with aortic and pulmonary insufficiency in the presence of a ventricular septal defect and infundibular pulmonic stenosis. Report of a case of forme fruste of the Marfan syndrome," Diseases of the Chest, vol. 50, no. 2, pp. 199-205, 1966.

[50] W. C. Roberts and H. S. Honig, "The spectrum of cardiovascular disease in the Marfan syndrome: a clinico-morphologic study of 18 necropsy patients and comparison to 151 previously reported necropsy patients," American Heart Journal, vol. 104, no. 1, pp. 115-135, 1982.

[51] A. G. Stuart and A. Williams, "Marfan's syndrome and the heart," Archives of Disease in Childhood, vol. 92, no. 4, pp. 351356, 2007.

[52] V. H. Yajnik, P. K. Kshatriya, M. H. Vaidya, and N. T. Vassa, "Marfan's syndrome, ventricular septal defect and basilar impression in one patient," Journal of the Indian Medical Association, vol. 64, no. 9, pp. 242-244, 1975.

[53] R. K. Beals and F. Hecht, "Congenital contractural arachnodactyly. A heritable disorder of connective tissue," Journal of Bone and Joint Surgery, vol. 53, no. 5, pp. 987-993, 1971.

[54] B. L. Callewaert, B. L. Loeys, A. Ficcadenti et al., "Comprehensive clinical and molecular assessment of 32 probands with congenital contractural arachnodactyly: report of 14 novel mutations and review of the literature," Human Mutation, vol. 30, no. 3, pp. 334-341, 2009.
[55] R. A. Anderson, S. Koch, and R. D. Camerini-Otero, "Cardiovascular findings in congenital contraction arachnodactyly: report of an affected kindred," American Journal of Medical Genetics, vol. 18, no. 2, pp. 265-271, 1984.

[56] A. J. Macnab, L. D’Orsogna, D. E. Cole, P. E. Baguley, R. J. Adderley, and M. W. Patterson, "Cardiac anomalies complicating congenital contractural arachnodactyly," Archives of Disease in Childhood, vol. 66, no. 10, pp. 1143-1146, 1991. 


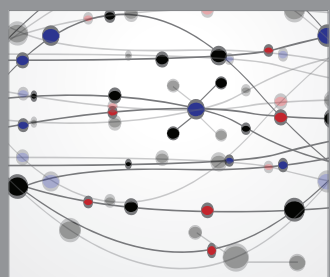

The Scientific World Journal
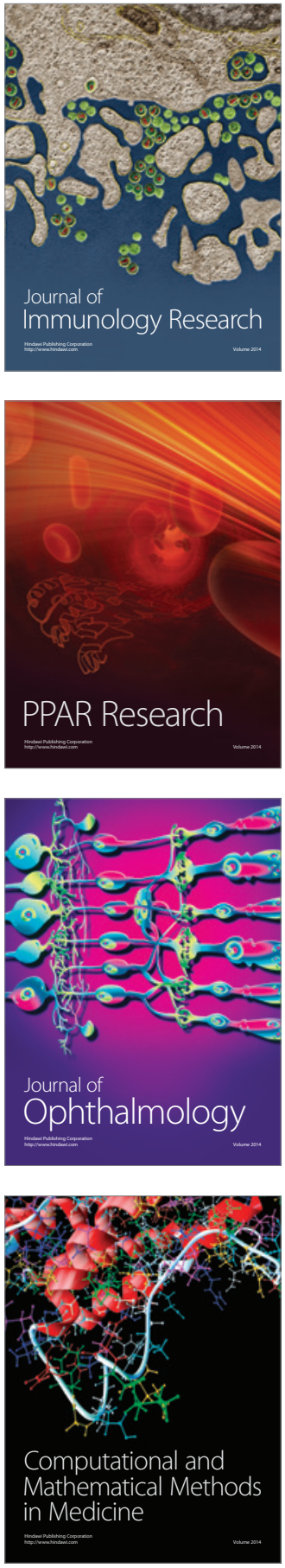

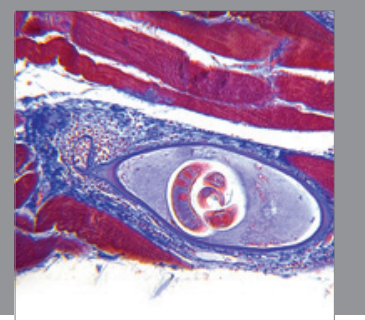

Gastroenterology

Research and Practice
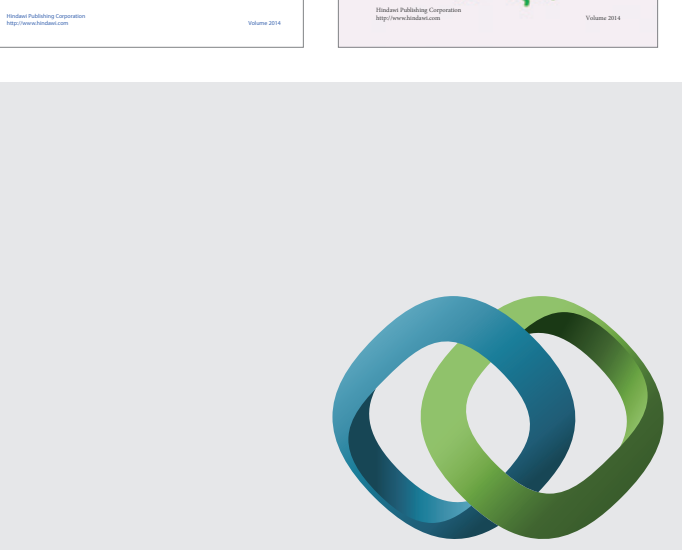

\section{Hindawi}

Submit your manuscripts at

http://www.hindawi.com
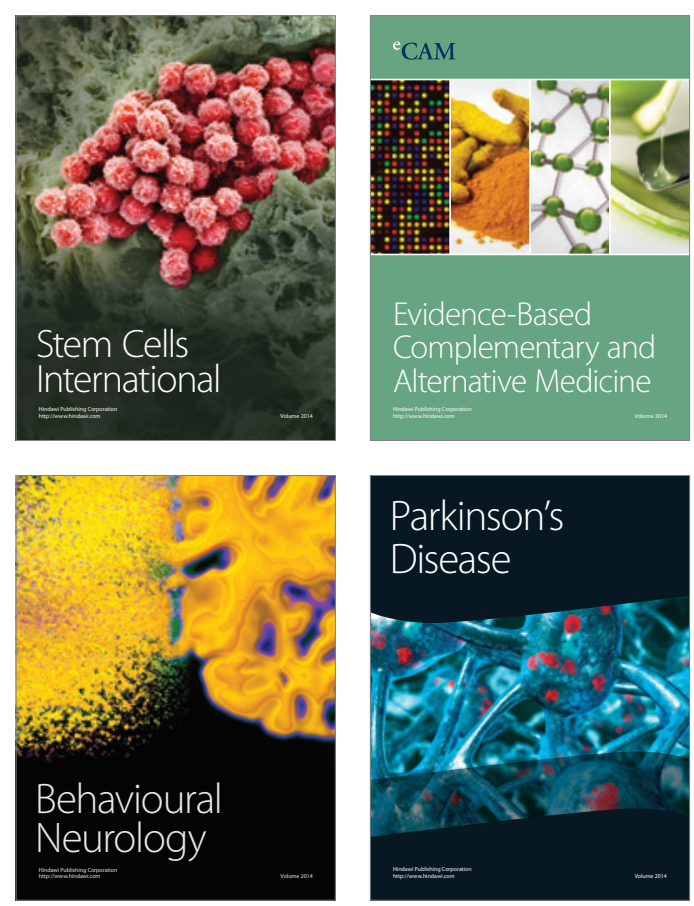

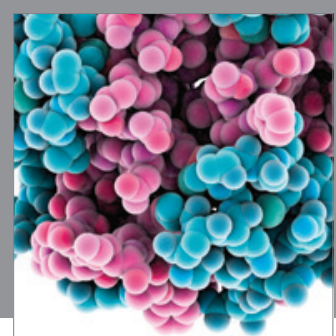

Journal of
Diabetes Research

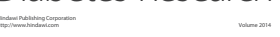

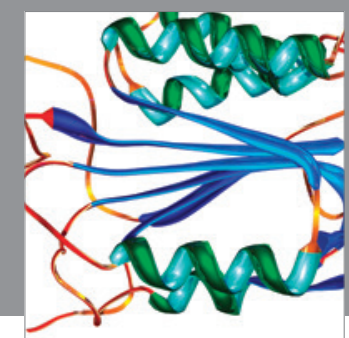

Disease Markers
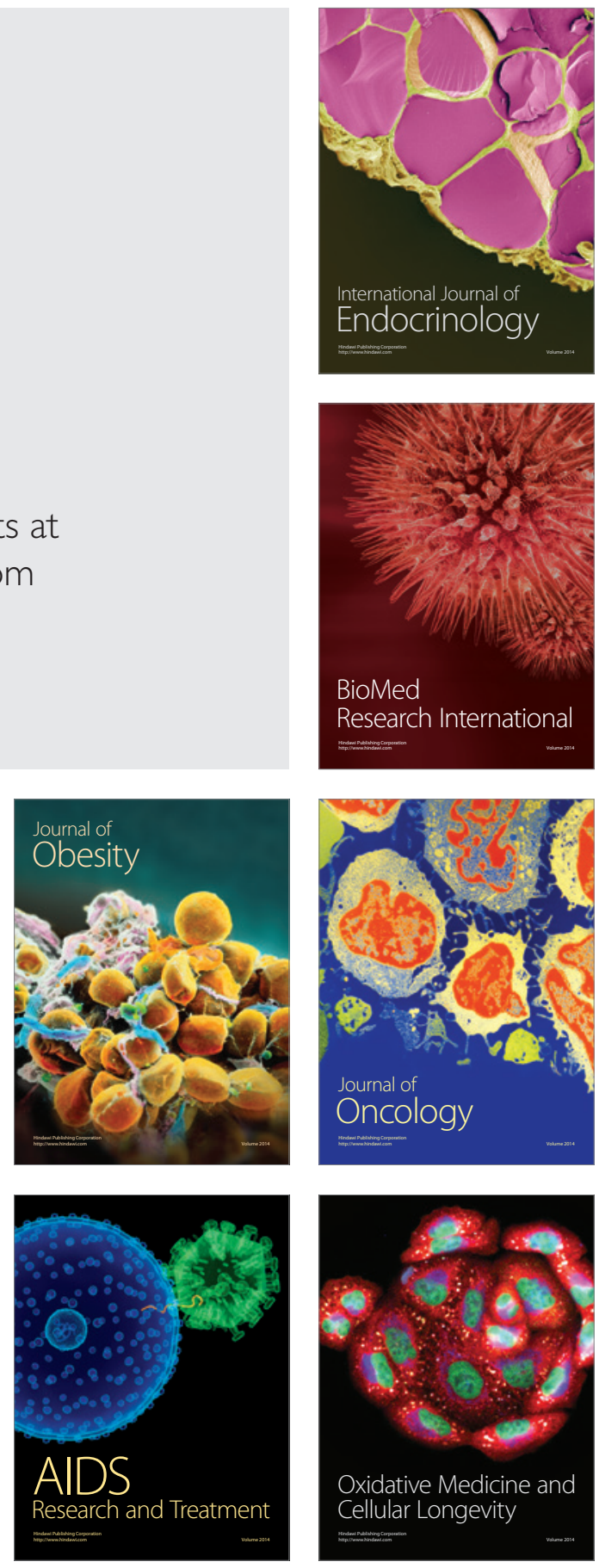